\title{
Research into Problems in the Implementation of Total Quality Management in University and Countermeasures
}

\author{
Gao $\mathrm{Lu}$ \\ Education Reform \& Teaching Quality Evaluation \\ Center \\ Bohai University \\ Jinzhou Liaoning \\ 36652078@qq.com
}

\author{
$\operatorname{Lin} \operatorname{Lin} *$ \\ Education Reform \& Teaching Quality Evaluation \\ Center \\ Bohai University \\ Jinzhou Liaoning \\ linlin3273@163.com
}

\begin{abstract}
The comprehensive reform in the field of education is in full swing. The implementation of Total Quality Management in Colleges and universities is the important content of building the characteristic first-class university. The implementation of Total Quality Management in universities plays a vital role in the promotion of modern universities. Study on these aspects can make contributions to the improvement of high education quality.
\end{abstract}

Keywords- Total Quality Management; High Education Quality Management; modern university system

\section{INTRODUCTION}

As the most basic and classic theory in the world, total quality management (TQM for short hereinafter) has received wide attention and is widely applied in the work of government, public sectors and enterprises [1]. TQM refers to: "take the quality as the center of an organization, based on full participation, aim is customer satisfaction and all the Organization's members and management approaches of the social benefit and achieve long-term success [2]. "Under the influence of the implementation of total quality management in the enterprise, last century, United Kingdom and the United States of part of the" introduction of a total quality management system in institutions of higher learning in school management and ISO9000 series standards, and try to implement total quality management. "[3] while total quality management means:" a University with the quality as the Center, based on faculty participation in the school, aimed at students and all school members and ways of management of society's benefits and to achieve long-term success. "[4]

\section{IT IS NECESSARY AND URGENT TO IMPLEMENT TOT AL QUALITY MANAGEMENT IN COLLEGES}

A. It is necessary to implement total quality management in colleges

1) Implement Total Quality Management in Colleges: due to the need of developing colleges themselves

Now, in a period of great development of higher education in China, their shoulders bear research project and the dual goals of this training. At this stage of market economy as the external environment, both the talent and the quality of scientific and technological achievements, will be integrated into the job market and market regulation, this is connected with the general business community. Domestic University external facing with universities all over the world in comprehensive influence, transforming scientific and technological achievements, quality and other aspects of competition. Internal facing domestic University students' quality, discipline, teachers, management and other as pects of the race. This survival of the fittest rules must continue to reform in colleges and universities, to change the traditional mode of development and talent training mode, therefore, reform and development, seek to feature in development, it has become an inevitable trend in the development of higher education. Colleges and universities to have strong core competitiveness, an invincible position in the fierce competition, it is necessary to apply the successful model of total quality management in the enterprise to colleges and universities, to promote the long-term and successful development.

2) Implement Total Quality Management in Colleges: due to the need of developing Market Economy

In recent years, the economy from "State macro-control market, Government policy guidance, market enterprises" new order has gradually formed, including their corresponding new mechanisms of higher education. Competition is the core of a new order, to commodities, commodity technology and quality competition, in terms of human resources is the talent competition, it boils down to competition in education, this new order's request, universities will have to straighten out the relationship between self and society, the Government. Market competition must catalyze the typed-behavior of the University. Paston pointed out that "there is an interdependent relationship of education and economy, either party will have significant causal influence on the behavior of the other." [5] Thus, the rapid development of the market economy requires implementation of total quality management in higher education, to standardize the school management, self-improvement and continuous improvement of established mechanism. Colleges and universities should establish a "market-oriented in order to survive and persist in reform and development", to be market-oriented, optimization of specialty structure, adjust 
the professional layout, to improve the quality of education, cultivate a real social need, talent for the enterprise.

\section{B. It is urgent to implement total quality management in colleges}

Since the last century, the expansion of higher education, making college students contradiction between quantity and quality of higher education. After the expansion of enrollment at the University, China's unprecedented access to higher education opportunities for students, but the University has become one of China's talents "factory". "Universities are supposed to cultivate principled, respected leader; should train students to important values, character, morals, so they are willing to study for the well-being of the peoples of the world."[6] And with the expansion of the conflict with the quality, and more and more the traditional management model has been unable to meet the need of colleges and universities.

Relying solely on modern teaching equipment or scholar does not make the quality higher and quality is made up of faculty in colleges and universities work together to create a high level of quality control of the results. To realize the function of management in colleges and universities, total quality management, mobilize the enthusiasm of staff, slow growth is the expansion of higher education and quality among the most pressing methods.

\section{MAIN PROBLEMS IN IMPLEMENTING TOT AL QUALITY MANAGEMENT IN COLLEGES}

Quality of higher education is the focus of the education sector through the world wide problem. Development of total quality management in some colleges and universities, as summed up in the Birnbaum: "management concepts from the enterprise was usually gleefully entered academe started publicity around compelling and cause indigestion in College, finally left quietly."[7] All of total quality management in the field of higher education since 2000 reflections, analysis of problems on its implementation in higher, mainly focus on the following three aspects:" to implement the "implementation of total quality management; awareness of the system is not perfect, rupture the unity of form and content requirements of quality management; the lack of quality supervision departments or administrative powers.

\section{A. Total Quality Management Implemented for \\ "Implementation"}

In China, the earliest implementation of total quality management of Dalian Maritime University, College of Qingdao marine University mainly to meet their needs in line with the international standards, so that trained people to gain access to international market access. "To implement the" implementation. Compared with them, United States imple mentation of TQM College is based on the successful implementation of its business, and in accordance with the dual needs of higher education to improve quality and reduce cost. And outside of the University for administrative intervention, underpowered compared to their intrinsic motivation apparently is active.

Passive imple mentation of total quality management in China's colleges and universities in higher education management in practice so much of the work is the lack of positive and reflect the understanding and practice of formalism. "Quality audit" audit, "to implement the" implementation of total quality management, is not a real consensus based on quality and urgency of survival.

\section{B. Imperfect Understanding of the Theory System, Dividing the Integration of Management Forms and Content Requirement}

Implementation of TQM system should have full support of the educational institutions in the design of the top, needs a good number of participants with relevant management experience. University of China, neither leadership nor the grass-roots management managers really know very little of the total quality management model. Total quality management of colleges and universities in China are limited to partial or limited the use of total quality management in the concept of an application at a specific level. Such as total quality management in University Library in the application, the application of total quality management in the management of teaching in colleges and universities, and so on. Due to lack overall understanding of the system in the whole system, and not fully comprehensive higher education system of governance in higher education.

Total quality management as a management model, you need standardization and under the premise of management by objectives, mission and tasks of the school translated into goals, targets assigned to each sector, and according to these objectives, in accordance with total quality management methods to the full, the entire process management, as sessment, so as to guarantee school goals to achieve. Due to awareness of the theory is not perfect, the fragmented unity of form and content requirements of quality management, does not lead to total quality management in higher education to play its due role.

\section{Department and Administrative Power with the Supervision of Quality Management}

Total quality management of colleges and universities includes setting goals, assessing performance and correct deviations, the latter two of which is the quality control and supervision. Needs including build ing monitoring and supervision of all quality management oversight mechanis $m$ and a third party evaluation system. This supreme power functions to the periodic evaluation of the performance of various departments. However, the reality is in the University: the University's lack of quality management office, universities and even set it to secondary teaching assistant Department, making it the Depart ment for lack of real executive power. Only to deal with regular external quality audits, these departments are "busy". And some lack of system in colleges and universities and has overall responsibility for internal quality audit, monitoring and Evaluation Department.

\section{PATHS FOR COLLEGES TO IMPLEMENT TOT AL QUALITY MANAGEMENT}

Total quality management in colleges and universities is a lasting and systematic work, real time, must complete a basic set of preparations. Total quality management system is the essence of disruptive changes in existing management model of colleges and universities, means of 
College staff ideological consciousness, organization management mode of rebuilding and remodeling. Therefore, the implementation of total quality management in colleges and universities, into implementation of the prepare phase, implementation phase with improved stages, by establishing the long-term success and quality of modern university management system, truly holistic grasp of University management and quality of service.

\section{A. Preparation for Implementing Total Quality Management}

Practice has proved that the reforms had little effect in colleges and universities, resulting in waste of manpower and resources, mainly because of conflict between traditional management models and new management model. Total quality management and traditional management mode of fundamental difference from the overall sense of quality as the Center. Implementation of total quality management in colleges and universities, reached in the first staff of the management theory of recognition and understanding. This means that each employee's work in colleges and universities must focus on "management" this overall target is run, all departments should be actively involved in the school activities to total quality management.

Specific application of the success of the reform depends on the attitude of the Executive. Therefore, the implementation of total quality management Foundation and the Foundation is to ensure that all staff understand what total quality management is.

Essential of TQM is an emphasis on "customer satisfaction, continuous improvement" as the core management philosophy. Lawrence and Robert said: "in higher education, taking customers as the Center is difficult, as far as academic institutions, not strictly identify appropriate consumer [7]." So, student-centered, consumer satisfaction with the concept must be integrated into the University's management culture, can have real effects. On total quality management knowledge in the preparation of short-term counselling and training through colleges and universities digital campus and modern third-party communication devices such as micro-circle of Friends campaign schedule management representative visited enterprises, universities, schools the successful implementation of total quality management, and so on. Eventually make every staff in understanding the nature of TQM in colleges and universities based on the essence of the concept of consciousness permeates every aspect of management activities in universities. The concept of total quality management in colleges and universities throughout the whole process, embodied in specific management actions, so that every employee to clarify their responsibilities and powers [8]. Colleges and universities to establish school-wide total quality management strategic plan for each employee on the basis of clear planning each of the decision-making, and specific goals, tasks, plan and indicators and their relationship, understand management system implementation, control, inspection, incentives for energy conservation on their own influence and role of the Department and I..

\section{B. Establish Modern College System}

If the total quality management is a systematic and comprehensive activities, establishing and perfecting the modern University system is a specific form of total quality management in colleges and universities; if the total quality management emphasis is on comprehensive long-term development strategy for all, establishing and perfecting the system of modern University: complete this strategy with tactical security. Implementing total quality management must establish a modern University system in colleges and universities, formed with University regulations for the core basis of the University management system [9].

At present, the construction of our university system, mostly confined to a few simple reforms such as: reform, professional development of school principals of teachers ' professionalization reform, performance management system reform, the reform of the personnel system. And for coordination of higher education, universities of the University system must be systematic and should be the one-way system reform supported by the reform. The so-called "unity of purpose" and "goals" established, you need the premise of comprehensive management, individual needs combined with organizational objectives. The University's mission and tasks into a series of objectives assigned to each sector, and based on the assessment of their departments, and to realize the management objectives of the University.

Modern University system consists of two levels: school system and University internal management mechanis m. Internal management mechanisms need to be developed under the concept of total quality management to protect and implement. Meaning of the modern University system is: "through coordination, standard University organization's internal and external relations, to ensure the University's cultural position, thereby enabling the University to better fulfil its responsibility for cultural heritage and cultural creativity."[10] These TQM concepts complement each other.

In the process of building a comprehensive quality management system of colleges and universities first and foremost principle of the system, namely system principles and objectives principles and normative principles. Taking into account long-term planning, combined with the existing school organization and its operation on the basis of sound operation of the quality system will be beneficial to the organization. Streamlined level bearing in mind the relationship between departments and personnel of articulation, the rational allocation of resources required to ensure that the quality system on the basis of actual participation by the quality of decomposition and determination of responsibilities. In addition, College services "satisfaction" low responsible for educators in colleges and universities is not strong, enthusiasm is one of the root causes of high enough job performance and personal interests do not closely. Therefore, the transformation of management system in colleges and universities, established performance appraisal oversight agencies and departments, and give the quality supervision Department the Executive power, is the key to ensuring quality management. 


\section{Establish Quality Standard System}

In the implementation of total quality management in colleges and universities, need to establish and guarantee for a sound system. To ensure effective operation of the quality system is a key step to prepare the quality system documents. This requires universities to establish the absence of uniform target runs, to mobilize all members of modern University system to achieve its development goals. Chinese universities lack the institutional system of global and proactive and forward-looking, namely "does not come out, not system" regulatory lag. Change of University, is actually the system change. Harvard University to be successful, the most important--the system is a set of innovative. United States view of institutionalism: a good system can make a bad man becomes good educators Yuan Zhenguo that "scientific systemcan improve efficiency".

Quality system documentation including quality procedures, policies, manuals, procedures, plans and records. Schools should form a variety of documented operating procedures and specifications, all of the elements included in the quality system. In addition, the establishment of an effective performance appraisal system, mobilize the enthusiasm of staff involved in the total quality management, making it a powerful guarantee for successful implementation of total quality management in colleges and universities.

\section{Continuous Improvement}

PDCA, Plan-, develop plans, policies and objectives; Do-implementation, operation, contents of the implementation plan; Check-check, summarize the results of the implementation plan, identify management problems; Action-action, Executive summary of the results of the plan, success be replicated and failures to avoid. Colleges and universities in the implementation of a comprehensive quality, PDCA cycle, and the whole school administration is a PDCA cycle, departments, faculties each component PDCA cycle. Large ring with a small ring, forming a continuous system. Next loop above based on the first cycle and level loop on the composition and guarantees. Form an organic whole and ensure that the entire system is turning toward the manage ment goals, promote each other, and seek common progress. To promote PDCA cycle, can fully reflect the principle of continuous improvement of comprehensive quality management. Discovering problems in action, sum up experience, problem-solving, program to integrate better into the work practices. Each time through the loop, part of the results achieved, and part of the solution, and work forward, improved. A cycle of problems left over from entering the next cycle, resolved by the next cycle. And so on, and all the work is always in a State of continuous improvement.

Implementation of total quality management, construction first-class universities, the D"National Plan for Medium and Long-term Education Reform and Development", and "Some Ideas about Improving the Quality of Higher Education" in the spirit of real and necessary requirement is the only way to achieve long-term development objectives in colleges and universities and school needs of survival and development under the conditions of market economy. Believe that the guarantee of total quality management theory in modern University system construction must achieve ongoing success.

\section{ACKNOWLEDGMENT}

2014 general project of national social science "research into theories of ecological treatment of China's higher education during the period of one-way competition"(14BGL105), Educational Sciences of Liaoning province "Twelve-Five" planning 2015 project "study on academic influence of educational research institutions in Liaoning province" (JG15DB034), the first teaching of the Liaoning Provincial Association for the evaluation of education reform and education quality evaluation research of the Liaoning Provincial education and research institutions for academic impact evaluation and improvement strategy study (PJHYYB15199) stage one. Educational science planning projects in Liaoning province "where the new barriers and solutions of talent training in colleges and universities (JG13DB174) stage one of the 2014-Bohai University education reform project" construction and adapted to a new undergraduate teaching reform research on teaching quality guarantee system (BDJG-14-WT-A-001) "initial results. Jinzhou City, social sciences circles" Union project "research on the function of local colleges and universities to improve social service path" stage.

\section{REFERENCES}

[1] Gong Yiming. Quality Management [M]. Shanghai. Fudan University Press, 2000:57.

[2] Shi Xiaoguang. Western Higher Education's Total Quality Management and Its Enlightenment on China [J]. Comparative Education Research, 2002 (2): 32-37.

[3] Lin Lin. Research of Implementing Total Quality Management in Local Higher Colleges and Universities [D]. Jinzhou: Bohai University, 2014.

[4] Lin Lin. Research of Implementing Total Quality Management in Local Higher Colleges and Universities [D]. Jinzhou: Bohai University, 2014.

[5] Xiao Ming. Comparative Analysis of Total Quality Management and ISO9000 Quality Management [J]. Theories and Practice of System Engineering, 1995(2): 63-68.

[6] [U.S.] Hari •Lewis. Excellence without Soul: How Harvard Forgets its Educational Aims [M]. Translated by Hou Dingkai, etc. Shanghai: East China Normal University Press, 2012:05.

[7] Sitalakshmi Venkatraman. A Frame-work for Implement ing TQM in Higher Education Programs[J].Quality Assurance in Education,2007(1):99-112.

[8] Yang Yandong. Research into Logistics Management and Reform of China's Colleges and Universities [M]. China Social Science Publishing House, 2012:93.

[9] Yang Yandong. My Outlook on Universities [M]. Liaoning Educational Electronic Audio and Video Publishing House, 2014:27.

[10] Zhang Yingqiang, Gao Guijuan. On the Cultural Orientation of Modern University System Construction [J]. Research of Higher Education, 2002(6): 28-331. 